\title{
Effect of Integrated Soil Fertility Management on Crop Production: A Review
}

\author{
Dereje Dobocha Goda* \\ Ethiopian Institute of Agricultural Research, Kulumsa Agricultral Research Center \\ P.O.Box 489, Assela, Ethiopia
}

\begin{abstract}
Maintaining soil fertility is one of the main factors affecting the sustainability of food production. Indiscriminate use of chemical fertilizers, coupled with neglected maintenance of the vitality of the soil and the use of destructive methods have caused loss or destruction of the existing population of soil organisms. The use of chemical fertilizer, organic fertilizer or bio fertilizer has its advantages and disadvantages in the context of nutrient supply, crop growth and environmental quality. The advantages need to be integrated in order to make optimum use of each type of fertilizer and achieve balanced nutrient management for crop growth. This review study showed that balanced fertilization using both organic and chemical fertilizers is important for maintenance of soil organic matter (OM) content and long-term soil productivity in the tropics where soil OM content is low. The basic concept underlying the ISFM is the adjustment of soil fertility and plant nutrient supply to an optimum level for sustaining desired crop productivity through optimization of the benefits from all possible sources of plant nutrients in an integrated manner. Therefore, increased attention should be being paid to developing an integrated soil fertility management that maintains or enhances soil productivity through balanced use of all sources of nutrients, including chemical fertilizers, organic fertilizers and bio fertilizers.
\end{abstract}

Keywords: Chemical Fertilizer, Organic Fertilizer, Integrated Soil Fertility Management

DOI: $10.7176 / \mathrm{JBAH} / 9-8-01$

Publication date: April $30^{\text {th }} 2019$

\section{Introduction}

Soils in sub-Saharan Africa are declining significantly, posing a major risk to food security. In expanding agriculture farmers deforest the existing land forest and expand agricultural land without organic matter management. Livestock productions on unprotected land lead to overgrazing process and bare the land of grasses, which directs the land to be liable to further degradation through erosion (Mulualem and Yebo, 2015). Thus, all these practices cause low soil fertility. Low Soil fertility is one of the major constraints affecting crop production in sub-Sahara Africa (Bekunda et al., 2010).In many parts of Africa repeated cultivation of land with inappropriate farming method is causing depletion of nutrients and organic matter. Studies have shown that there is negative balance of nitrogen, phosphorus and potassium in most sub Saharan African countries. Soil fertility depletion factors in small holder farmers are fundamental cause for declining per capital food production in sub Saharan Africa (Endris and Dawid, 2015).

Although Chemical fertilizers has great role in intensification of crop production, due to lack of adequate supply and lack of affordability the yield of crop is low as compared with potential yield. Alliance for green in Africa (AGRA), suggested that huge gap in yield existing between Sub Sahara Africa (SSA) and developed world can be closed by managing soil nutrient and proper agricultural practices (Sanginga, 2012).Farmer's perception knowledge is very valuable, for instance in some part of Ethiopian farmers realized that fertilizer application gives better yield when follow a rotation of some kind legume crop. Therefore, combined different farming system and agronomic practices can help to solve the problems of soil fertility (Mulualem and Yebo, 2015).

Some integrated soil fertility management (ISFM) interventions have seen large adaption across SSA (Vanlauwe et al., 2010). ISFM can give benefit to production and livelihood of farmers; the resilience of cropping system to climate change impacts and mitigation of greenhouse gas from fertilizers and soil. Besides ISFM is a means to increase crop productivity in a profitable and environmentally friendly way. ISFM is a technology that combines a mix of organic and inorganic fertilizers used in order to maximize nutrient use efficiency of soil (Hintsa et al., 2016). Research on the determination on optimum of organic and inorganic source could be increased in yield and sustainability of soil fertility. Thus, ISFM can help farmers in improving nutrient use efficiency and reducing cost of inorganic fertilizer. Therefore, the objective of this paper is to review different components of integrated soil fertility managements and its effect on crop production.

\section{Soil Fertility Status of Sub Saharan Africa}

Soils are an integral component of agriculture and serve as medium for numerous eco-biological, chemical and physical processes (Omotayo and Chukwuka, 2009). Therefore it is needed to manage soil resource in order to achieve optimum productivity (Omotayo, 2009). The goal of soil management is to create healthy environment 
which retain balanced nutrient status monitored over time. Soil productivity maintenance remains a major environmental issue in countries of SSA (Feller et al., 2012). Countries like SSA, unsuitable soil management activities including deforestation, indiscriminate vegetation removal, overgrazing and use of marginal lands for agricultural purposes often increases degradation of soils and environmental damage (Henao and Baanante, 2006). Decline in soil fertility as a result of land degradation decreases farmland productivity. Estimates indicated that a net loss of about $700 \mathrm{~kg}$ of N, $100 \mathrm{~kg}$ of P and $450 \mathrm{~kg}$ of K per hectare in about 100 million hectares of cultivated lands over the last 30 years of several countries in SSA (Ibrahim et al., 2015). Many parts of SSA where poor soil conservation methods prevail, long term productivity of soil is projected to decline considerably unless soil management practices improve. A World Bank report estimated the rate of cereal yield increase in sub Saharan Africa over the years at a very low rate of $0.7 \%$ compared to growth rates in other developing regions of the world of $1.2-2.3 \%$ (Bell et al., 2008). These decreases trend of yield may be the cause for food security problem in sub Saharan countries. This review highlights the recent advances in soil improvement activities in SSA countries through employment of organic amendments.

\section{Integrated soil Fertility Management}

Maintaining soil fertility is one of the main factors affecting the sustainability of food production. Indiscriminate use of chemical fertilizers, coupled with neglected maintenance of the vitality of the soil and the use of destructive methods have caused loss or destruction of the existing population of soil organisms (Geisseler and Scow, 2014; Ebrahimi et al., 2016).ISFM was defined as a set of soil fertility management practices that necessarily include the use of fertilizer, organic inputs, and improved germplasm combined with the knowledge on how to adapt these practices to local conditions, aiming at maximizing agronomic use efficiency of the applied nutrients and improving crop productivity. All inputs need to be managed following sound agronomic principles (Vanlauwe and Zingare, 2011).Thus; ISFM includes combination of both organic and inorganic source in a sustainable way to improve crop productivity. Integrated soil fertility integrates organic and inorganic methods of soil fertility managements with physical and biological measures of soil and water conservation. It integrates technologies that are site specific to agronomic and socio economic conditions to redress nutrient imbalance and organic matter deterioration and it focus on judicious use of mineral fertilizers, maximizes organic fertilizers and reducing environmental impacts (Sommer et al., 2013). Waste lands are converted high fields on the same lands for many years by eliminating the needs for clearing new lands by using integrated soil fertility management, better use of organic materials available on farm to build up soil organic matter (Hintsa et al., 2016). ISFM also considers the knowledge of farmers so that it is easy to adapt and economical rather than depending entirely on inorganic fertilizers. Research has identified intensification options in agricultural production including integrated options such as combined use of organic and inorganic inputs, micro dosing of fertilizers, legume-cereal integration through rotations and intercropping, conservation agriculture and agro forestry options, among others (Vanlauwe et al., 2015).The goal of sound soil management is to create a healthy soil environment which may retain balanced nutrient status such that its fertility is maintained over time. The use of external inputs is a nutrient management option that has attracted the most studies in SSA. Several decades of research showed that deficiencies of macronutrients such as N, P, and K are major limitations to crop production (Ayalew, 2011; Aleminew and Legas, 2015; Argaw and Tsigie, 2015), and lately the limitations of secondary nutrients and micronutrient deficiencies are gaining traction (Habtegebrial, 2013).

\section{Use of Mineral Fertilizers}

Mineral fertilizers are materials, either natural or manufactured, containing nutrients essential for the normal growth and development of plants. Plant nutrients are food for plants some of which are used directly for human food, others to feed animals, supply natural fibers or produce timber (Mosier et al., 2013). Man and all animals depend entirely on plants to live and reproduce. Nitrogen, phosphate and potash fertilizers are primary mineral fertilizers produced by the fertilizer industry. Mineral fertilizers are required to supplement the nutrients recycled or added in the form of crop residues and animal manures. Fertilizers are concentrated sources of essential nutrients in a form that is readily available for plant uptake (Fairhurst, 2012). Chemical fertilizers provide shortterm nutrient needs of agricultural products, and long-term soil fertility is fallen into oblivion by farmers and agricultural producers. Moreover, the common fertilization system is focused on providing a limited number of macronutrients, while it is scientifically known that plants need at least 13 available minerals in the soil (Atiyeh et al., 2000). Studies have shown that the excessive and unbalanced use of chemical fertilizers in the long run decreases crop yield, biological activity, soil physical properties, and increases accumulation of nitrates and heavy metals and soil acidity (Aseri et al., 2008; Yoshida et al., 2016). Other studies have proven that continued use of chemical fertilizers reduces crop yield due to soil acidification, loss of soil physical and chemical characteristics, and the lack of appropriate micronutrients in these fertilizers (Ghimire et al., 2017). 


\section{Use of organic source}

In organic source the nutrient is released at slower rate when compared with mineral fertilizers. To make the nutrient available they should decomposed with microorganisms (Hintsa et al., 2016). The use of organic source helps to increase crop response to mineral fertilizers, improving moisture ability of soils, adding nutrients that do not contained by mineral fertilizer, creating better rooting environment, replenishing soil organic matter (Fairhurst, 2012). Study indicated that use of organic fertilizers increases soil organic matter, improves microbial activity, and provides both macro- and micronutrients required for the plant in a more efficient way (Angin et al., 2017).Research designated that organic fertilizer has some limitation. Transporting large amount of organic fertilizers is difficult to transport especially when it is manure and slurry which incurs high cost. The composition of organic fertilizers lands to be manure complex and variable than a standardized in organic product from plant or animals matter that are harmful to humans or plant (Hintsa et al., 2016). Soil organic matter (SOM) plays a crucial role in maintaining sustainability of cropping systems by improving soil physical, chemical and biological properties (Diacono and Montemurro, 2011; Fageria, 2012). Organic farming has become a part of the global agricultural industry and therefore organic products are traded not just between farmers and regions but between countries and continents (JÄRVAN et al., 2017). Some of the organic resources are reviewed below.

\section{A. Compost}

Compost is rotting down of plant or animal residue (remains) in heap or pits before the residue is applied to the soil. In the preparation of the compost, the rate of decomposition is controlled by the aeration condition and water contents of the pits. Composting affects the physical and chemical properties of the soil. Organic matter (compound) introduced with the compost to the soil and produced by the subsequent biological activity work to promote soil aggregation and enhance aggregate stability (Bot, 2005). Regarding to its effect in chemical properties of soil, Buzie-Fru (2010) stated that when compost is incorporated in soil there are immediate calculable changes in the concentrations of nutrients trace metals and other chemical compounds that result from the application rate and composition of two materials. It has a role in changing $\mathrm{PH}$ of the soil due to their content of carbonate and organic matter; the carbonate makes rise in $\mathrm{PH}$ while the organic matters buffers the system somewhere neutral (Fijałkowski et al., 2012).It is indicated that regular addition of organic materials, particularly the composted ones, increased soil physical fertility, mainly by improving aggregate stability and decreasing soil bulk density (Diacono and Montemurro, 2011). On the other hand, composts can have direct effects against disease, as well as stimulation of the competing microorganisms and also development of resistance in plants against diseases (Ebrahimi et al., 2018). Addition of organic materials of various origins to soil has been one of the most common practices to improve soil physical properties (Celik et al., 2004).In line with this finding a field experiment was conducted by Ebrahim et al. (2019) for two years continuously to evaluate the influence of using four different soil conditioners: cow manure (CM), household compost (HC), spent mushroom compost (SMC), and vermin compost (VC). Results indicated that treatments with CM showed significantly higher tomato yield in the first year $\left(103 \mathrm{t} \mathrm{ha}^{-1}\right)$ compared to other composts, but in the second year, SMC produced a higher yield $\left(58 \mathrm{t} \mathrm{ha}^{-1}\right)$. In contrast to this result, Mehdizadeh et al. (2013) showed that HC had a significantly better effect as compared to CM, poultry manure, and sheep manure, in cumulative tomato yield and the number of tomato per plant. In the proposed study, there was a reduction on tomato yield in the second year due to warm weather during the transplanting phase. Therefore composting has a positive effect in maintain soil fertility.

\section{B. Farm yard manure}

Organic agriculture is a production system which relies on ecosystem management and ecological processes rather than on the external flow of agricultural inputs (Foissy et al., 2013). Well-rotted farmyard manure is a soilenriching product, produced from organic matter that helps to boost the nutrient levels and properties of the soil. Why use farmyard manure? Farmyard manure (FYM) is a valuable soil improver that enhances and restores a range of natural properties of the soil. Related to this JÄRVAN et al. (2017) reported that FYM is one of the more valuable organic fertilizers maintaining soil fertility in the systems of alternative agriculture. Maintenance and improvement of soil potential fertility are closely related to the maintenance of soil organic matter and organic carbon balance (Bakšienè et al., 2014). On organic farms, where the importation of materials to build and maintain soil fertility is restricted, it is important that a balance between inputs and outputs of nutrients is achieved to ensure both short-term productivity and long-term sustainability (Foissy et al., 2013). The sustainability of stockless organic farming systems is questioned, noticeably those that were located in regions where resources of organic matter are scarce. Only farming systems producing large quantities of manure or which purchased feed showed balanced nutrient budgets (Foissy et al., 2013). Farmyard manures are the major source of nutrient supply also on small farm holdings (Fageria, 2012). As stated by Smith and Williams (2016), cattle manure comprised $80 \%$ of the total UK animal livestock manure production during the housing period, there at about $53 \%$ of this was estimated to be as solid, mainly straw-based cattle manure. In the intensive 
livestock farms with a limited area of agricultural land there is a risk of over-fertilizing with manure, which may result in increased nutrient leaching and groundwater contamination (JÄRVAN et al., 2017). The long-term lysimetric experiments on a sandy loam Luvisol showed that the intensive application of straw-based cattle manure (at $300 \mathrm{~kg} \mathrm{ha}^{-1} \mathrm{~N}$ rate annually) resulted in great amounts of nitrogen and calcium leached from the soil (Tripolskaja et al., 2016). Beneficial effect of farm yard manure is increase availability and mobility of Phosphorus and micro nutrients. Experiment conducted at Haramaya University showed that FYM in combination with mineral fertilizers gave good yield in hybrid Maize (BH -140) from the treatments 4 ton ha ${ }^{-1}$ FYM $+75 \mathrm{~kg} \mathrm{~N}^{-1}$ with $60 \mathrm{~kg} \mathrm{P}^{-1}$ performed best among others, with maize yield of 8.16 tons ha-1(Mulualem and Yebo,2015). Another experiment conducted at Haramaya University indicated that the combined analysis of variance on hybrid maize (BH-140) yield and harvest index over years showed the presence of no significant difference among treatments with 10 tons/ha FYM and $100 \mathrm{~kg} / \mathrm{ha} \mathrm{N}+100 \mathrm{~kg} \mathrm{P} / \mathrm{ha}$ (Bekeko, 2013). The impact of animal manure depends on soil texture (JÄRVAN et al., 2017). According to Dunjana et al. (2012), the addition of cattle manure resulted in significant $(\mathrm{P}<0.01)$ increases in soil organic carbon (SOC), macroaggregate stability and aggregate protected carbon in clay soils. However, the addition of cattle manure on sandy soils, in contrast, increased significantly $(\mathrm{P}<0.05)$ only SOC but had no impact on soil bulk density and aggregate stability. Addition of animal manure may increase biodiversity in the soil, thereby causing alteration in composition, size, and activity of soil microorganisms and enzyme activities (Watts et al., 2010).

\section{Green Manuring}

Green manure is a type of cover crop grown primarily to add nutrients and organic matter to the soil. Green manuring may be defined as a practice of ploughing or turning into the soil un-decomposed green plants or their residue for the purpose of improving physical structure and fertility of a soil (Pandey \& Singh, 2016).Organic manures were considered as the cheap and chief source of plant nutrients and soil amendment. Complete dependence on chemical fertilizers is making the soil unfertile and less productive in absence of organic material besides soils (Nayak and Vaidya, 2018). A green manure crop is grown for specific period of time and then ploughed under and in corporate in the soil (Hintsa et al., 2016). A green manure is a crop used primarily as a soil amendment and a nutrient source for subsequent crops (Cherr et al., 2006). The practice of green manure provides many improvements in chemical, physical and biological characteristics, through increases in organic matter content and microbial activity, nutrient cycling, disruptions of compacted layers, decreased erosion, incidence of pests and diseases, and suppression of weed plants for sustainable fruit production system (Zaccheo, 2016). Organic matter in soil is an imperative indicator of soil fertility (Rahman, and Parkinson,2007) which can improve soil structure, nutrient exchange and maintain soil physical conditions (Schröder,2005). It also reduces the level of carbon dioxide in the atmosphere that contributes positively to climate change (Lal,2016). The benefit of using green manuring is addition of nitrogen. When the non-legume plant is buried under only $\mathrm{N}$ from the soil is returned to the crop. For example, multi-purpose soyabean varieties used for food, feed and soil fertility improvement provide a large biomass that benefits the next crop in the rotation in addition to an acceptable grain yield (Fairhust, 2012). The other importance of green manuring is to control soil erosion because it improves the soil structure thus improves water holding capacity of the soil. It is a well-known fact that use of green manure increase the yield of crops, however it is not practical by most farmers in Ethiopia for most reasons that most trees provided for this purpose are exotic, and the trees are slow growing, and research attention is not given in this area (Haile, 2012). Green manuring improves water holding capacity of the soil, especially in sandy soils, where losses of nutrients occur due to fast downward movement of water (Nayak and Vaidya, 2018). Green manures increase soil microbial biomass and activity and cause distinct changes in soil microbial populations that may be partially responsible for suppression of diseases (Larkin, 2013). Soil borne pathogens causes crop yield losses in many plants (Oerke , 2006). Effect of green manuring on fungal diseases like the rhizoctonia root rot disease of bean was caused by Sclerotinia spp. and it was reduced by the decomposition of green plant materials (Pung et al., 2004). Biological control against nematodes could also be possible by green manure (Agbenin et al., 2011). Green manures increases pathogen inhibitory activity within the streptomycete community in soil in conjunction with crop rotation and control the soil-borne plant pathogens (Wiggins and Kinkel, 2005).

\section{Integrated Effect of Organic and In Organic Source Fertilizers on Crop Productivity}

Integrated plant nutrient management is the application of inorganic fertilizer in combination with organic fertilizer to maintain soil fertility and to balance nutrient supply in order to boost up the crop yield per unit area (Mahajan et al., 2008; Roberts, 2010). Emerging evidence indicated that integrated nutrient management involving the judicious use of organic and inorganic resources is a feasible approach to overcome soil fertility constraints (Abedi et al., 2010). Kaur et al. (2008) stated that a judicious combination of organic amendments and inorganic fertilizers is widely recognized strategy of integrated nutrient management to sustain agronomic productivity and improve soil fertility. Several researchers have demonstrated the beneficial effect of combined 
use of chemical and organic fertilizers to mitigate the deficiency of many secondary and micronutrients in fields that continuously received only $\mathrm{N}, \mathrm{P}$ and $\mathrm{K}$ fertilizers for a few years, without any micronutrient or organic fertilizer. In line with this Arif et al.(2014) reported that application of poultry manure $10 \mathrm{tha}^{-1}$ in combination with $50 \%$ of recommended dose of fertilizer increased grain yield of rice by $32 \%$. Authors also stated, the higher yield obtained with integrated use of organic manure and inorganic fertilizers was attributed to increased nutrient availability and uptake, resulting in greater number of fertile tillers, number of grains per panicle, number of panicles per hill, filled grains per panicle, 1000 grain weight, biological yield, grain yield and harvest index. On the other hand, Shah et al.(2010) concluded that the best wheat yield was obtained from plots, which received $25 \% \mathrm{~N}$ from farm yard manure with either $25 \%$ from city waste or poultry waste and $50 \%$ mineral $\mathrm{N}$ (urea) than of plot receiving only inorganic nitrogen. The results were similar with that of Abera et al. (2018) who reported significantly higher grain yield and biomass yield of barley were obtained with the application of sole recommended NP and the integrated use of 50:50\% vermin compost and conventional compost with recommended NP. Another experiment conducted in central highland of Ethiopia on integrated soil fertility in wheat and teff showed that the organic carbon content increase under organic and combination of organic and in organic condition. Application of inorganic or organic nutrient sources alone or mixed has significant effect on wheat grain yield, total biomass and harvest index but didn't affect the thousand grain weight. Higher yield, total biomass and straw yield was obtained from the combination of organic and inorganic compounds yield increase was over $100 \%$ ( Agegnehu et al., 2014). The same is true that grain yield, total biomass, straw yield has also responded for combined use of organic and in organic plant nutrients. Another experiment conducted on the effect of integrated soil fertility on Maize in acidic Nitosols in southwestern Ethiopia, on three sites Burka, Wenji and Waktola showed that the highest grain yield recorded at the site of Wenji and Waktola is on treatments of recommended 50\% NP $+50 \%$ Tithiona biomass and recommended 50\% $\mathrm{NP}+50 \%$ compost respectively with grain yield of $4684.3 \mathrm{~kg} \mathrm{ha}^{-1}$ and $3936.8 \mathrm{~kg} \mathrm{ha}^{-1}$ (Endris and Dawid, 2015). Thus, integrating organic and in organic sources of nutrients can give better yield than sole application of inorganic fertilizers in most cases and also be economical rather than depending on entirely on inorganic fertilizers and also helps maintain soil fertility which a concern especially in Sub Saharan Africa.

\section{Conclusion}

Integrated soil fertility management helps to reduce considerable amount of inorganic fertilizers. Organic fertilizers enhance effect use of inorganic fertilizers and it also reported that integrated use of organic residues with inorganic one helps to reduce the cost by 25\%. Furthermore, use of inorganic soil ameliorates in conjunction with slow release mineral has the advantages of increasing the nutrient storage capacity of the soil. In developing countries like Ethiopia with low input utilization of fertilizers, integrated use of organic and inorganic fertilizers can be a solution. Application of mineral fertilizers demand high cost. A high degree of variability in crop response to nutrients and amendments is observed in major crop growing areas in SSA. Therefore, by integrating inorganic fertilizers and organic fertilizers which are available or prepared by using local material yield increment can be attained with sustainable soil fertility management. In a nutshell, future research could be give due attention to developing an integrated plant nutrition system that maintains or enhances soil productivity through balanced use of all sources of nutrients, including chemical fertilizers, organic fertilizers and bio fertilizers in SSA.

\section{References}

Abedi, T., Alemzadeh, A., \& Kazemeini, S. A. (2010). Effect of organic and inorganic fertilizers on grain yield and protein banding pattern of wheat. Australian journal of crop science, 4(6), 384.

Abera, T., Tufa, T., Midega, T., Kumbi, H., \& Tola, B. (2018). Effect of Integrated Inorganic and Organic Fertilizers on Yield and Yield Components of Barley in Liben Jawi District. International Journal of Agronomy, 2018.

Agegnehu, G., Vanbeek, C., \& Bird, M. I. (2014). Influence of integrated soil fertility management in wheat and tef productivity and soil chemical properties in the highland tropical environment. Journal of soil science and plant nutrition, 14(3), 532-545.

Aleminew, A., \& Legas, A. (2015). Grain quality and yield response of malt barley varieties to nitrogen fertilizer on brown soils of Amhara region, Ethiopia. World Journal of Agricultural Sciences, 11(3), 135-143.

Angin, I., Aslantas, R., Gunes, A., Kose, M., \& Ozkan, G. (2017). Effects of sewage sludge amendment on some soil properties, growth, yield and nutrient content of raspberry (Rubus idaeus L.). Erwerbs-obstbau, 59(2), 93-99.

Argaw, A., \& Tsigie, A. (2015). Indigenous rhizobia population influences the effectiveness of Rhizobium inoculation and need of inorganic $\mathrm{N}$ for common bean (Phaseolus vulgaris L.) production in eastern Ethiopia. Chemical and Biological Technologies in Agriculture, 2(1), 19.

Arif, M., Tasneem, M., Bashir, F., Yaseen, G., \& Iqbal, R. M. (2014). Effect of integrated use of organic 
manures and inorganic fertilizers on yield and yield components of rice. J. Agric. Res, 52(2), 197-206.

Aseri, G. K., Jain, N., Panwar, J., Rao, A. V., \& Meghwal, P. R. (2008). Biofertilizers improve plant growth, fruit yield, nutrition, metabolism and rhizosphere enzyme activities of pomegranate (Punica granatum L.) in Indian Thar Desert. Scientia horticulturae, 117(2), 130-135.

Atiyeh, R. M., Subler, S., Edwards, C. A., Bachman, G., Metzger, J. D., \& Shuster, W. (2000). Effects of vermicomposts and composts on plant growth in horticultural container media and soil. Pedobiologia, 44(5), 579-590.

Ayalew, A., Kena, K., \& Dejene, T. (2011). Application of NP Fertilizers for better production of Teff (Eragrostis tef (Zucc.) Trotter) on different types of soils in southern Ethiopia. Journal of Natural Sciences Research, 1(1), 6-11.

BAKŠIENĖ, E., RAŽUKAS, A., REPEČKIENĖ, J., \& TITOVA, J. (2014). Influence of different farming systems on the stability of low productivity soil in Southeast Lithuania. Zemdirbyste-Agriculture, 101(2), $115-124$.

Bekeko, Z. (2013). Improving and sustaining soil fertility by use of enriched farmyard manure and inorganic fertilizers for hybrid maize (BH-140) production at West Hararghe zone, Oromia, Eastern Ethiopia. African Journal of Agricultural Research, 8(14), 1218-1224.

Bekunda, M., Sanginga, N., \& Woomer, P. L. (2010). Restoring soil fertility in sub-Sahara Africa. In Advances in Agronomy (Vol. 108, pp. 183-236). Academic Press.

Bell, D. E., Milder, B., \& SHELMAN, M. (2008). Alliance for a green revolution in Africa (AGRA). Harvard Business School.

Bot, A., \& Benites, J. (2005). The importance of soil organic matter: Key to drought-resistant soil and sustained food production (No. 80). Food \& Agriculture Org.

Buzie-Fru, C. A. (2010). Development of a continuous single chamber vermicomposting toilet with urine diversion for on-site application.

Celik, I., Ortas, I., \& Kilic, S. (2004). Effects of compost, mycorrhiza, manure and fertilizer on some physical properties of a Chromoxerert soil. Soil and Tillage Research, 78(1), 59-67.

Cherr, C. M., Scholberg, J. M. S., \& McSorley, R. (2006). Green manure approaches to crop production. Agronomy Journal, 98(2), 302-319.

Diacono, M., \& Montemurro, F. (2011). Long-term effects of organic amendments on soil fertility. In Sustainable Agriculture Volume 2 (pp. 761-786). Springer, Dordrecht.

Dunjana, N., Nyamugafata, P., Shumba, A., Nyamangara, J., \& Zingore, S. (2012). Effects of cattle manure on selected soil physical properties of smallholder farms on two soils of Murewa, Zimbabwe. Soil Use and Management, 28(2), 221-228.

Ebrahimi, E., Asadi, G., \& und Niemsdorff, P. V. F. (2019). A field study on the effect of organic soil conditioners with different placements on dry matter and yield of tomato (Lycopersicon esculentum L.). International Journal of Recycling of Organic Waste in Agriculture, 8(1), 59-66.

Ebrahimi, E., Bagheri, A., \& von Fragstein und Niemsdorff, P. (2016). Assessment of undersown white clover (Trifolium repens L.) on organic leek (Allium porrum L.) performance (yield and nutrient uptake). Int J Adv Agric Res, 4, 46-50.

Ebrahimi, E., Werren, D., \& und Niemsdorff, P. V. F. (2018). Suppressive effect of composts from residual biomass on Pythium ultimum. Journal of Plant Diseases and Protection, 125(5), 443-449.

Endris, S., \& Dawid, J. (2015). Yield response of maize to integrated soil fertility management on acidic nitosol of Southwestern Ethiopia. Journal of Agronomy, 14(3), 152-157.

Fageria, N. K. (2012). Role of soil organic matter in maintaining sustainability of cropping systems. Communications in Soil Science and Plant Analysis, 43(16), 2063-2113.

Fairhurst, T. (2012). Handbook for integrated soil fertility management. Technical Centre for Agricultural and Rural Cooperation.

Feller, C., Blanchart, E., Bernoux, M., Lal, R., \& Manlay, R. (2012). Soil fertility concepts over the past two centuries: the importance attributed to soil organic matter in developed and developing countries. Archives of Agronomy and Soil Science, 58(sup1), S3-S21.

Fijałkowski, K., Kacprzak, M., Grobelak, A., \& Placek, A. (2012). The influence of selected soil parameters on the mobility of heavy metals in soils. Inżynieria i Ochrona środowiska, 15, 81-92.

Foissy, D., Vian, J. F., \& David, C. (2013). Managing nutrient in organic farming system: reliance on livestock production for nutrient management of arable farmland. Organic agriculture, 3(3-4), 183-199.

Geisseler, D., \& Scow, K. M. (2014). Long-term effects of mineral fertilizers on soil microorganisms-A review. Soil Biology and Biochemistry, 75, 54-63.

Ghimire, R., Lamichhane, S., Acharya, B. S., Bista, P., \& Sainju, U. M. (2017). Tillage, crop residue, and nutrient management effects on soil organic carbon in rice-based cropping systems: A review. Journal of integrative agriculture, 16(1), 1-15. 
Habtegebrial, K., Mersha, S., \& Habtu, S. (2013). Nitrogen and sulphur fertilizers effects on yield, nitrogen uptake and nitrogen use efficiency of upland rice variety on irrigated Fulvisols of the Afar region, Ethiopia. Journal of Soil Science and Environmental Management, 4(3), 62-70.

Haile, W. (2012). Appraisal of Erythrina bruci as a source for soil nutrition on nitisols of South Ethiopia. International Journal of Agriculture and Biology, 14(3).

Henao, J., \& Baanante, C. (2006). Agricultural production and soil nutrient mining in Africa: Implications for resource conservation and policy development.

Hintsa Meresa, Zelalem Mengistu, Misene Bisetegn. (2016). Effects of Integrated Soil Fertility Management on Sustainable Crop Production. Journal of Economics and Sustainable Development 7(1): 25-30.

Ibrahim, Y., Balzter, H., Kaduk, J., \& Tucker, C. (2015). Land degradation assessment using residual trend analysis of GIMMS NDVI3g, soil moisture and rainfall in Sub-Saharan West Africa from 1982 to 2012. Remote Sensing, 7(5), 5471-5494.

JÄRVAN, M., Vettik, R., \& Tamm, K. (2017). The importance and profitability of farmyard manure application to an organically managed crop rotation. Zemdirbyste-Agriculture, 104(4).

Kaur, T., Brar, B. S., \& Dhillon, N. S. (2008). Soil organic matter dynamics as affected by long-term use of organic and inorganic fertilizers under maize-wheat cropping system. Nutrient Cycling in Agroecosystems, 81(1), 59-69.

Lal, R. (2016). Soil health and carbon management. Food and Energy Security, 5(4), 212-222.

Larkin, R. P. (2013). Green manures and plant disease management. CAB Reviews, 8(37), 1-10.

Mahajan, A. N. I. L., Bhagat, R. M., \& Gupta, R. D. (2008). Integrated nutrient management in sustainable ricewheat cropping system for food security in India. SAARC Journal of Agriculture, 6(2), 29-32.

Mehdizadeh, M., Darbandi, E. I., Naseri-Rad, H., \& Tobeh, A. (2013). Growth and yield of tomato (Lycopersicon esculentum Mill.) as influenced by different organic fertilizers. International journal of Agronomy and plant production, 4(4), 734-738.

Mosier, A., Syers, J. K., \& Freney, J. R. (Eds.). (2013). Agriculture and the nitrogen cycle: assessing the impacts of fertilizer use on food production and the environment (Vol. 65). Island Press.

Mulualem, T., \& Yebo, B. (2015). Review on integrated soil fertility management for better crop production in Ethiopia. Sky J. Agricultural Research, 4(1), 21-32.

Nayak, J.J., Vaidya, Dr.A.C.(2018). Green Manure in Crop Production and Soil Health. International Journal of Innovative Research in Science, Engineering and Technology, 7(6):2347-6710.

Oerke, E. C. (2006). Crop losses to pests. The Journal of Agricultural Science, 144(1), 31-43.

Omotayo, O. E., \& Chukwuka, K. S. (2009). Soil fertility restoration techniques in sub-Saharan Africa using organic resources. African Journal of Agricultural Research, 4(3), 144-150.

Pandey A. K and Singh M. K. (2016). Importance and uses of green manuring in field crops. Rashtriya krishi. 11(2): $35-35$.

Pung, H., Aird, P. L., \& Cross, S. (2004, February). The use of Brassica green manure crops for soil improvement and soil borne disease management. In Proc. Third Australas. Soilborne Dis. Symp. Barossa, SA, Australia.

Rahman, S., \& Parkinson, R. J. (2007). Productivity and soil fertility relationships in rice production systems, Bangladesh. Agricultural systems, 92(1-3), 318-333.

Roberts, T. L. (2010, August). Nutrient best management practices: Western perspectives on global nutrient stewardship. In 19th World Congress of Soil Science, Soil Solutions for a Changing World, p172-75, Brisbane, Australia.

Sanginga, N. (2012). Closing the yield gap through integrated soil fertility management (No. 658-2016-44639, p. 77).

Schröder, J. (2005). Revisiting the agronomic benefits of manure: a correct assessment and exploitation of its fertilizer value spares the environment. Bioresource technology, 96(2), 253-261.

Shah, S. A., Shah, S. M., Wisal, M., Shafi, M., Haq, N., Samreen, S., \& Amir, M. (2010). Effect of integrated use of organic and inorganic nitrogen sources on wheat yield. Sarhad Journal of Agriculture, 26(4), 559-563.

Smith, K. A., \& Williams, A. G. (2016). Production and management of cattle manure in the UK and implications for land application practice. Soil Use and Management, 32, 73-82.

Sommer, R., Bossio, D., Desta, L., Dimes, J., Kihara, J., Koala, S., ... \& Winowiecki, L. (2013). Profitable and Sustainable Nutrient Management Systems for East and Southern African Smallholder Farming Systems Challenges and Opportunities: A synthesis of the Eastern and Southern Africa situation in terms of past experiences, present and future opportunities in promoting nutrients use in Africa.

Tripolskaja, L., Baksiene, E., Razukas, A., \& Sidlauskas, G. (2016). How Organic Fertilizers Change Chemical Element Leaching: A Summary of the Lysimeter Studies in Lithuania, 1987-2014. Polish Journal of Environmental Studies, 25(6).

Vanlauwe, B., \& Zingore, S. (2011). Integrated soil fertility management: An operational definition and 
consequences for implementation and dissemination. Better Crops, 95(3), 4-7.

Vanlauwe, B., Bationo, A., Chianu, J., Giller, K. E., Merckx, R., Mokwunye, U. ... \& Smaling, E. M. A. (2010). Integrated soil fertility management: operational definition and consequences for implementation and dissemination. Outlook on agriculture, 39(1), 17-24.

Vanlauwe, B., Descheemaeker, K., Giller, K. E., Huising, J., Merckx, R., Nziguheba, G., ... \& Zingore, S. (2015). Integrated soil fertility management in sub-Saharan Africa: unravelling local adaptation. Soil, 1(1), 491-508.

Watts, D. B., Torbert, H. A., Feng, Y., \& Prior, S. A. (2010). Soil microbial community dynamics as influenced by composted dairy manure, soil properties, and landscape position. Soil science, 175(10), 474-486.

Wiggins, B. E., \& Kinkel, L. L. (2005). Green manures and crop sequences influence alfalfa root rot and pathogen inhibitory activity among soil-borne streptomycetes. Plant and Soil, 268(1), 271-283.

Yoshida, H., Nielsen, M. P., Scheutz, C., Jensen, L. S., Bruun, S., \& Christensen, T. H. (2016). Long-term emission factors for land application of treated organic municipal waste. Environmental Modeling \& Assessment, 21(1), 111-124.

Zaccheo, P. V. C., Neves, C. S. V. J., de Cinque Mariano, D., Zorzenoni, T. O., Higashibara, L. R., Piccinin, G. G., \& Okumura, R. S. (2016). Green manure in fruticulture: Aspects on soil quality and use in agriculture. African Journal of Agricultural Research, 11(17), 1469-1474. 